Article

\title{
Structures of Organisation and Loci of Authority in a Glocal Islamic Movement: The Tablighi Jama'at in Britain
}

\author{
Riyaz Timol \\ School of History, Archaeology and Religion, Cardiff University, Cardiff CF10 3AT, UK; TimolR1@cardiff.ac.uk \\ Received: 29 June 2019; Accepted: 2 October 2019; Published: 14 October 2019

\begin{abstract}
The Tablighi Jama'at (TJ) is widely regarded as the largest grassroots Islamic revival movement in the world, but it remains significantly under-researched. This paper, based on sustained ethnographic fieldwork conducted between 2013 and 2015, provides a comprehensive overview of the movement's organisational structures and loci of authority in Britain. It describes how different levels of the movement interact, from the local and regional to the national and international, to constitute a truly glocal movement. TJ's European headquarters, located in Dewsbury, West Yorkshire, is identified as a centralised hub that for several decades has co-ordinated the movement's activities in the West through the devoted leadership of Hafiz Muhammad Patel (1926-2016) and ongoing contact with the global spiritual centre in Nizamuddin, New Delhi. TJ's simultaneous links with hundreds of mosques across the country, largely — though not exclusively—of Deobandi orientation, are also described. The functioning of its regional centres of operation in Birmingham, Blackburn, Glasgow, Leicester and London is elaborated with reference to key weekly meetings convened on-site and the "routing" of numerous TJ groups to various British mosques each weekend. Although TJ's leadership has recently become embroiled in schism, the paper argues for the successful establishment of a robust institutional infrastructure in Britain which has facilitated the movement's transmission to a generation of British-born activists.
\end{abstract}

Keywords: Tablighi Jama'at; British mosques; Dewsbury Markaz; Hafiz Patel; Nizamuddin; Islamic revival; Deobandi; Muslims in Britain

\section{Introduction}

\subsection{A Quiet Revolution: The Spiritual Soft Power of a Global Islamic Movement}

From humble beginnings in 1920s British India, the Tablighi Jama'at-an apolitical and quietist movement of mass Islamic revivalism - has today developed into "one of the most important grassroots Islamic movements in the contemporary Muslim world" (Reetz 2009, p. 293). With tens of millions of followers across the globe (Mandaville 2010, p. 44), its influence extends across both Muslim-majority as well as diaspora settings, and its large headquarter complexes (markaz) can be seen dotted across numerous continents. Its distinct style of activism seeks to reinvigorate basic Islamic piety among Muslim masses through the constant formation and dispatch of small groups (jama'at) of itinerant lay preachers to sympathetic mosques around the world (Masud 2000). While the movement's core raison d'être is $d a^{\prime} w a$, or Islamic proselytization, it has no formal mechanism for inviting non-Muslims to the faith, but instead focusses its energies on bringing lapsed Muslims (of various denominational affiliations) into the fold. Despite a rigid uniformity of method, recent studies have chronicled its impact in regions as geographically disparate as Australia (Ali 2012), The Gambia (Janson 2014), South East Asia (Noor 2012), Kyrgyzstan (Balci 2015) and Pakistan (Khan 2016). However, its quiet and 
unassuming style of activism, coupled with its general policy of avoiding publicity and resisting research, has allowed it to flourish while frequently escaping the attention of academics and political commentators. In Britain, TJ has-along with its Deobandi cognate-exercised considerable influence in the establishment of Islam since the post-war settlement of Muslim communities from South Asia (Ahmed 2019, p. 154; Lewis 1994). For around 40 years, the movement's European headquarters has operated out of an imposing mosque complex located in Dewsbury, West Yorkshire, which also houses a residential Islamic seminary (dar al-ulum) providing theological training for future imams. However, despite the international furore sparked by the so-called 'London mega-mosque' controversy (Birt and Gilliat-Ray 2010; Pieri 2015), relatively little is known about the movement's internal organisation and modalities of operation in the UK. The most influential piece of research on British TJ-which continues to inform journalistic accounts or those inspired by Christian mission (Bowen 2014; Taylor 2015)—was carried out by Yoginder Sikand in the mid-1990s (Sikand 1998a). This paper, based on sustained and unprecedented ethnographic fieldwork undertaken with British TJ from 2013-2015, therefore aims to fill this lacuna by providing an insight into the movement's structures of organisation and loci of authority in Britain and beyond.

\subsection{A Historical Précis of TJ in Britain}

The history of TJ in Britain may be conceptualised in terms of three distinct phases. The first, chronicled in detail by Sikand (1998b), loosely extends from the time of the movement's arrival in the post-war period to the point at which a British-born generation of activists became increasingly involved in the early 1990s. During this time, TJ helped consolidate the religious identity of freshly uprooted immigrants by recreating, in diaspora, norms of life familiar from the country of origin. Given the mosque-based nature of its activism, TJ also expedited the process of community formation by contributing to the rapid proliferation of new mosques across the country (King 2002). In tandem with its Deobandi cognate, it also developed an institutional infrastructure of Islamic schools and seminaries aimed at preserving Muslim identity in a non-Muslim setting (Gilliat-Ray 2006; Birt and Lewis 2012). The tireless dedication of Hafiz Muhammed Patel, TJ's European amir (leader), was the conduit through which much of the activism of these decades came to fruition (Shaw 2016).

The second phase stretches from the increasing involvement of the British-born generation (although this process began gaining momentum from the late 1980s, I identify 1994 as a watershed year due to the convocation of a huge number of international TJ activists at the Dewsbury headquarters-popularly known as the '1994 World Ijtima' - which catalysed the process of intergenerational transmission (Timol 2017)) until the death of Hafiz Patel in 2016. During these years, thousands of British-born youth spent time with the movement—often visiting the international headquarters in India, Pakistan and Bangladesh on an extended four-month khuruj (outing)—many of whom remain active adherents to this day. While the movement's British core remains firmly in the control of elderly first-generation migrants, the periphery was increasingly appropriated during these decades by large numbers of English-speaking, secular educated youth ${ }^{1}$ who are now in their $40 \mathrm{~s}$ and 50s, and who exercise increasing influence in the movement's hierarchy. This phase also saw the increased participation of numerous British converts to Islam and Muslims of non-South Asian ethnic origin although they, in the UK context, remain a minority. Finally, this phase saw the consolidation of British TJ's national presence through the establishment of dedicated regional centres in Birmingham, Blackburn, Glasgow, Leicester and London in addition to the constant dispatch of British TJ groups to destinations across Europe as well as North and South America (Timol 2015). Despite TJ's significance on the landscape of British Islamic youth activism during this period, it remains characteristically

1 Janson's (2014) analysis of TJ's support base in The Gambia similarly identifies a core constituency of English-speaking, secular-educated youth. This challenges Sikand's dated assumption, based largely on the impassioned invectives of Gloucester-based pamphleteer Ebrahim Rangooni and the opinions of Hizb ut-Tahrir spokesperson Farid Kassim, that "The Tablighi Jama'at has very little presence among Muslim students in British schools and colleges" (Sikand 1998b, pp. 185-86). 
under-studied and is often conspicuous by its absence in the academic literature; Sadek Hamid's notable studies of the subject, for example, are resoundingly silent about TJ (Hamid 2011, 2015). ${ }^{2}$ My research therefore provides the first significant insight into the movement's appeal to British-born Muslim youth during these years (Timol 2017).

The third phase commences from Hafiz Patel's death in February 2016. While for many TJ activists this was experienced as an immeasurable loss (Timol 2016), it coincided with an internal schism in the movement's international leadership that came to public prominence after violent clashes were reported at the worldwide Nizamuddin headquarters in New Delhi during Ramadan 2016. ${ }^{3}$ The core issue was one of successorship; following the death in 2014 of Maulana Zubair-ul-Hasan ibn Inamul-Hasan Kandhalwi, one of TJ's global spiritual leaders, disagreement broke out as to whether Maulana Muhammad Sa'ad Kandhalwi, the great-grandson of TJ's founder Maulana Muhammad Ilyas Kandhalwi, should take sole leadership of the movement, or whether a global shura (council) should be formed. Discussions became heated, and eventually a 13-man council was formed in November 2015 despite Maulana Sa'ad's vehement objections. For the first time in its history, the movement's global leadership cleaved into two opposing factions: one supporting Maulana Sa'ad's continued leadership operating out of the historical headquarters in Nizamuddin, while the other pledged allegiance to the council of elders (aalami shura) whose de facto base became the Raiwind headquarters in Pakistan. Many of TJ's national chapters thus splintered-a situation that has led to acrimonious disputes at the level of individual mosques and families across the globe. ${ }^{4}$ British TJ certainly has not been immune, and the movement's national council of elders, based in Dewsbury, as well as those managing the various regional centres, became locked in bitter dispute during 2017. The content of this paper, however, is based upon fieldwork conducted between 2013 and 2015-prior to the death of Hafiz Patel. It therefore chronicles the structures of authority and modalities of operation which have characterised the movement in Britain for the great majority of its history.

\subsection{A Methodological Excursus}

The findings of this paper derive from qualitative fieldwork undertaken between 2013 and 2015, which principally examined the appeal of TJ to British-born Muslims. An ethnographic approach was taken in which I immersed myself in the subjective life-worlds of contemporary British TJ activists as a reflexive participant observer for a period of 18 months (Madden 2010; Coffey 1999; Hammersley and Atkinson 2007). This involved several overnight stays at the European headquarters in Dewsbury, participation in a fully-fledged TJ khuruj to Bulgaria for 42 days with experienced British-born activists (Timol 2015), and sustained participation in the daily TJ activities of a single mosque located in the North of England. During Ramadan 2014, I also participated in two ten-day outings to Bradford and Birmingham, respectively, with jama'ats consisting mainly of college and university students on their summer holidays. Additionally, I conducted 59 interviews-25 formal and recorded, with consent forms, and 34 informal and jotted while in the field —-with a wide spectrum of Muslims with differing experiences of TJ, including senior leaders, disillusioned critics and youthful neophytes experimenting with the movement for the first time. My prior familiarity with TJ, to which I was first exposed while studying at college over 20 years ago, coupled with my personal identity as the visibly Muslim offspring of South Asian migrants to the UK, helped me navigate the linguistic and cultural worlds of my respondents with relative ease, quickly developing the trust and rapport necessary for access. My fieldwork was limited, however, to the male experience of TJ given the guidelines of strict gender

2 Hamid's important book Sufis, Salafis and Islamists does not mention TJ once, while his paper British Muslim Young People: Facts, Features and Religious Trends erroneously states that "The seminary in Bury in North-West England is ... the international headquarters of the international Tablighi Jamaat missionary movement" (Hamid 2011, p. 256).

3 See, for instance, https://www.okhlatimes.com/tablighi-jamaat-members-clash-markaz/ (accessed 21 June 2019).

4 While this development is yet to be captured in the academic literature, it has been widely reported in South Asian media and the subject of much animated discussion within Muslim communities (see, for instance, Iqbal (2018) or Ghazali (2018)). 
segregation that govern the movement (Amrullah 2011). Taken together, my fieldnotes and interview transcripts produced a dataset in excess of 800,000 words which I meticulously checked and thematically coded using the qualitative data analysis software NVivo.

The objective of this paper is primarily descriptive. Drawing upon these fieldwork experiences, it seeks to improve our understanding of TJ by documenting its institutional infrastructures in Britain and meticulously sketching its core modalities of operation. It first describes the centrality of the Dewsbury headquarters for the functioning of British TJ before probing the extent to which TJ has managed to access mosques of various denominational orientations. The interaction of TJ's local, regional, national and international dimensions is then described by suggesting a parallel with the "episcopal polity" of British Christianity. The paper then foregrounds a case-study of TJ's Blackburn Markaz to examine how the movement's regional headquarters manage a constant flow of incoming and outgoing TJ groups, especially over peak weekend periods. Lastly, TJ's functioning on the interface of the local and global is described to argue for a normative glocal praxis that resides at the heart of the movement's operational dynamics.

\section{Dewsbury as A Central Hub}

The legal entity under which TJ operates in Britain is the "Anjuman-e-Islahul Muslimeen of United Kingdom" (The Society for the Reformation of Muslims in the United Kingdom) which has been a registered charity since 25 June 1975 . The principal aims of this charity, in its own words, ${ }^{5}$ are as follows:

- $\quad$ "To make provisions for the religious education of Muslim adults and children;

- To arrange and hold religious gatherings;

- To establish mosque and religious education schools;

- To attempt to create understanding of the Muslim religious issues amongst government institutions ${ }^{6}$;

- To make arrangements for groups of persons to visit mosques in the United Kingdom and overseas for the purpose of religious learning and spiritual self-rectification."

The charity is registered at the national headquarters of TJ, which is located on South Street in Savile Town, Dewsbury, in an enormous mosque complex that dominates the skyline (see Figure 1). The existing structure was built between 1978-1982 and was intended, with the approval of international TJ authorities, to be the base of the movement's activities in the West. By 'the West', a broad geographical purview is meant that initially covered Europe and North America but was later expanded, I was told by a long-standing TJ activist, to include South America. The amir (leader) of the Dewsbury headquarters, and by extension of TJ in the West, was - until his death in February 2016 aged 90-Hafiz Muhammad Patel, a dynamic Gujarati who devotedly coordinated TJ's Western activities for over 50 years since migrating to England in the 1960s. I was able to meet Hafiz Patel (as he is invariably referred to) several times during the course of my fieldwork and witnessed first-hand the reverence in which he was held; many regarded him a kaamil wali (fully accomplished saint) and he functioned as a Sufi shaykh for a sizeable number of British TJ activists who had taken the formal Sufi pledge of allegiance (bay'ah) with him (see Figures 2 and 3). ${ }^{7}$

5 Reproduced from the Annual Report filed with the Charity Commission for the year ending 31 December, 2014: http://apps.charitycommission.gov.uk/Showcharity/RegisterOfCharities/CharityWithPartB.aspx? RegisteredCharityNumber $=505732 \&$ SubsidiaryNumber $=0$ (accessed 21 June 2019).

6 Although a stated aim, in practice it appears that the British branch of the Tablighi Jama'at has preferred to eschew all but necessary contact with government throughout its history. This becomes all the more apparent when their approach is contrasted with other organisations such as the Muslim Council of Britain for example.

7 For more on Hafiz Patel, see the series of articles penned by the respected Leicester-based Deobandi scholar Maulana Muhammad Saleem Dhorat (2018). Although the Sufi roots of the Tablighi Jama'at are undeniable, the extent to which it can 


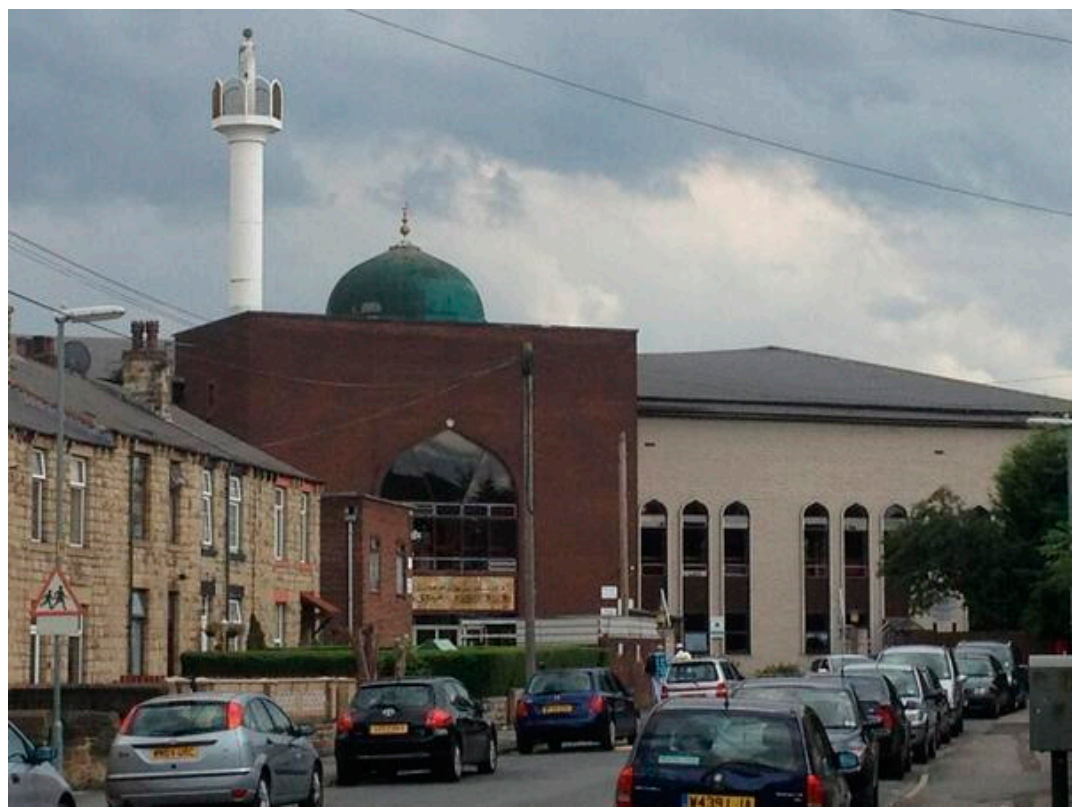

Figure 1. The Tablighi Jama'at (TJ) headquarters in Dewsbury, West Yorkshire. Source: http://www. beautifulmosque.com/Markazi-Mosque-in-Dewsbury-United-Kingdom (accessed on 21 June 19).

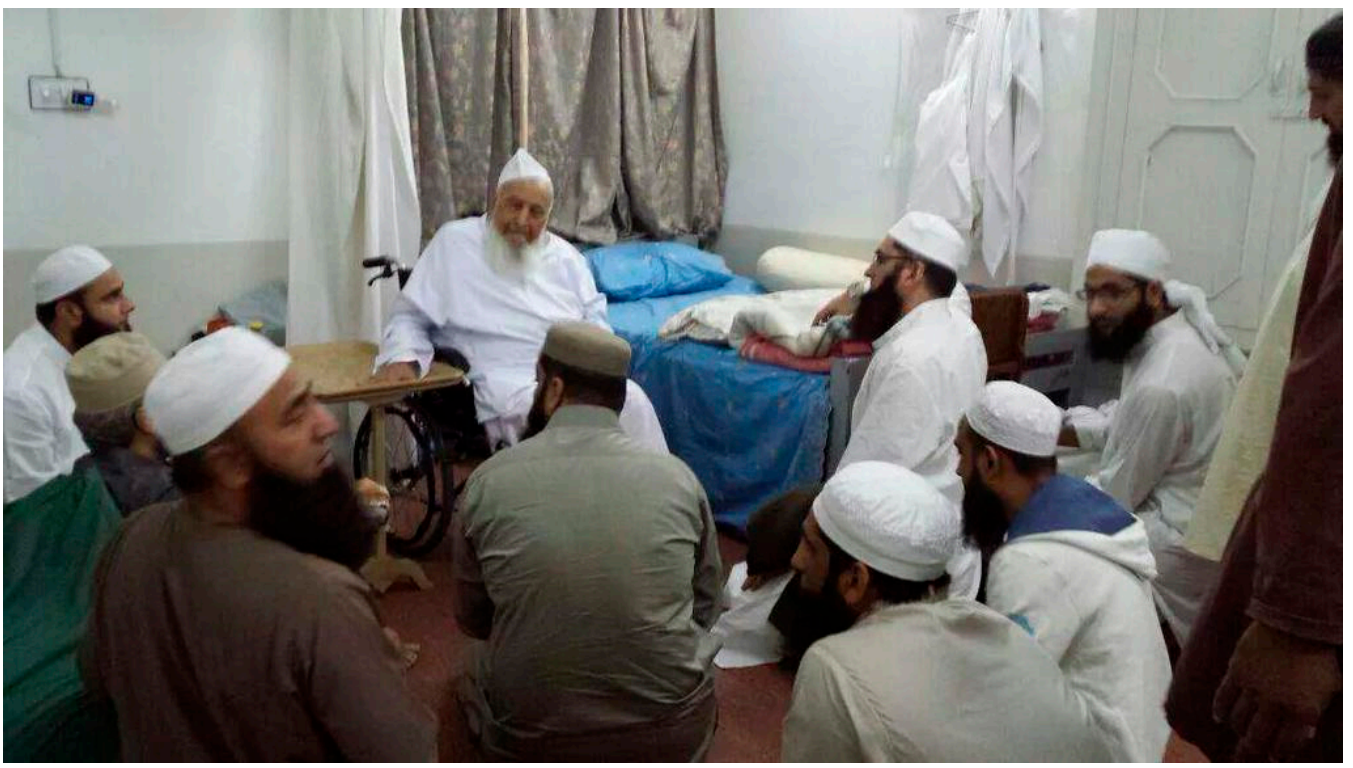

Figure 2. "With one of my favorite elders. Hafiz Patel sahib of Dewsbury UK. Raiwind ijtema 2014. Myself Saeed Yusaf n Sohail". Tweeted by the popular Pakistani popstar-turned-preacher Junaid Jamshed on 19 November 2014 (Hafiz Patel is in the wheelchair) during the annual TJ convocation (ijtima) held at Raiwind, near Lahore. Also visible in the photo are Pakistani cricketing heroes Saeed Anwar and Mohammad Yousuf (formerly Yousuf Youhana), both of whom became dedicated TJ activists through the influence of Maulana Tariq Jameel, a massively popular global spokesperson for the movement whose visits to the UK invariably draw crowds of many thousands. For more on Jameel, see Schleifer (2018, p. 107) and: https://www.asianexpress.co.uk/2014/12/world-famous-islamic-scholarreturns-to-bradford/ (accessed on 21 June 2019)). Source: https://twitter.com/junaidjamshedpk/status/ 535185271126757376 (accessed on 21 June 2019). 

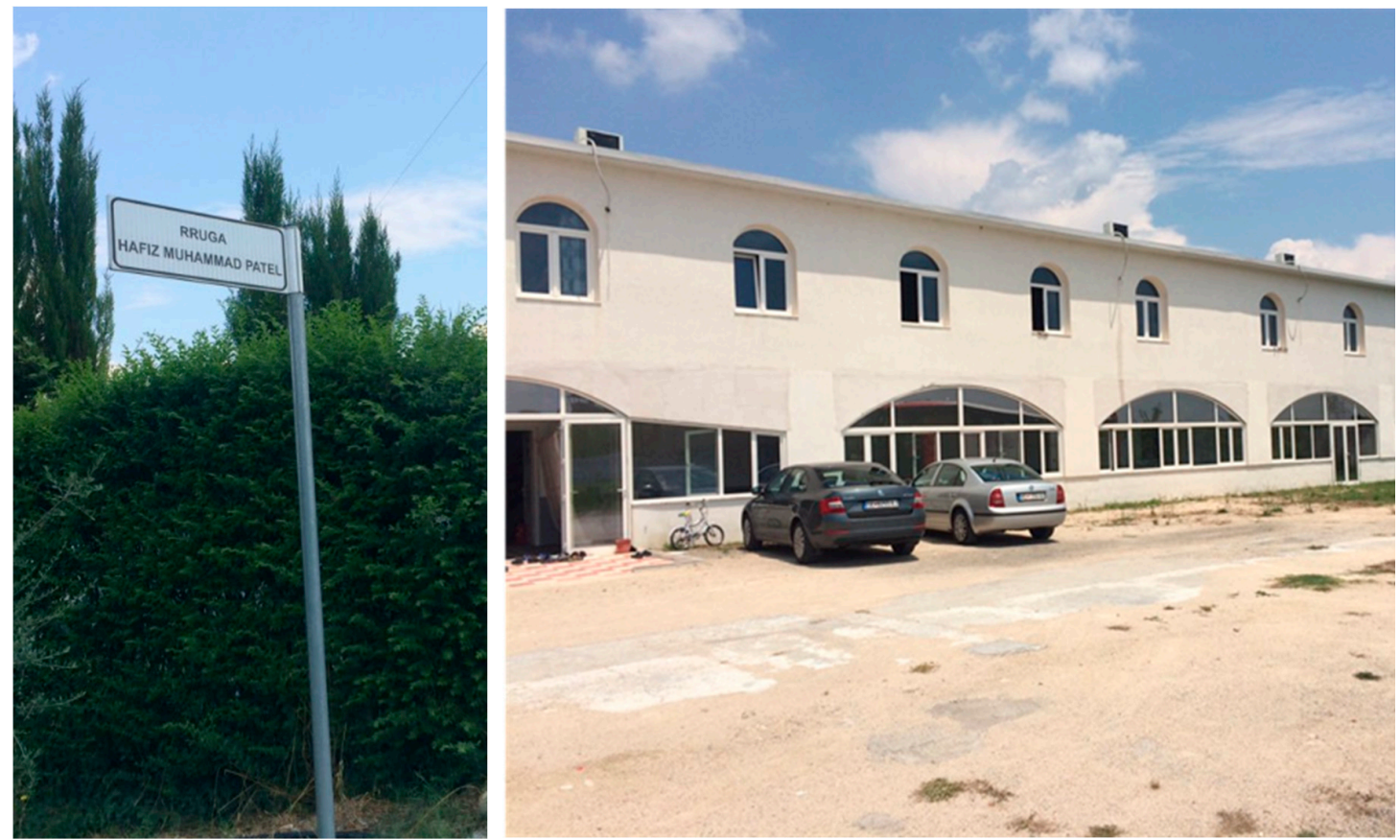

Figure 3. "Earlier today our convoy led by Mufti Muhammad Taqi Usmani and Mufti Ahmed Khanpuri arrived at Tirana Markaz, Albania. The road leading to the Markaz is named after Marhum [Deceased] Hafiz Patel, reflecting his lifelong commitment and dedication to propagating Deen [Religion]." Tweeted by (Mufti) Yusuf ibn (Mufti) Shabbir on 22 June 2018. Source: https: //twitter.com/ibn_shabbir/status/1010196457125707776 (accessed on 21 June 2019).

According to Abubakr, a senior British TJ leader I interviewed for over 5 hours, the decision to locate the movement's national base at Dewsbury was essentially fortuitous:

"So what happened was, Hafiz sahib, initially ... he worked for a few weeks in Preston ... Because the work was in Preston, a factory called Courtaulds ... So Hafiz sahib and Ishaq Patel ${ }^{8}$ — two of the ... founders of Tabligh in this country, they got a job in Courtaulds ... then because of the incident in Courtaulds [they were refused time off to offer their Friday prayers] they left and went to Nuneaton. There was no markaz established in Dewsbury at that time, and even though there was a community of Muslims there, Gujarati Muslims, they didn't have an alim (religious scholar), they didn't have a hafiz (somebody who has memorised the Qur'an). But they'd heard about Hafiz Patel, so they said this person in Nuneaton, why don't we bring him over? So they actually sort of head-hunted him to come to Dewsbury, and that's how it all [began] ... He was the imam there and then established the markaz there, so that's how Dewsbury became a foundation... Allah's will that it happened in Dewsbury." ${ }^{\prime 9}$

In addition, Dewsbury's location at the geographic centre of the UK may have been a contributory factor in that it facilitates the frequent travel that TJ activists make to the national headquarters from around the country. The importance of the Dewsbury headquarters as a centralised hub that co-ordinates international TJ activities in the West can be gauged by the fact that every outgoing TJ tour that exceeds 10 days in length must start and finish its journey in Dewsbury, irrespective of where

8 This seems to be the same Ishaq Patel reluctantly interviewed by Geaves (1996, pp. 171-77) during his visit to Dewsbury Markaz in 1993.

9 Sikand (1998b, p. 180) has essentially the same account, although he makes no mention of the stint in Preston and has Hafiz Patel moving to Dewsbury from Coventry rather than Nuneaton. All respondents I interviewed have been anonymised to protect their identity. 
in the UK the group originates from. For example, a group of Scottish youngsters who decide to spend their summer holidays on a 40-day TJ khuruj would, as the first step, make their way to Dewsbury Markaz, where a group leader (amir) would be appointed and the destination of their tour decided upon. They might spend the first two days at the headquarters where they would be expected to participate in the prayers and speeches delivered throughout the day before being dispatched, for example, to London for the next 37 days. Their first point of landing in London would be the regional TJ markaz (centre) located in West Ham where they might spend a day; regional TJ leaders there would assess the group and accordingly decide, through the core TJ act of mashwera (mutual consultation), the specific boroughs and mosques they should visit for the remainder of their tour. The bulk of the 40-day trip would then be spent travelling through a range of London mosques in which the group would stay for no more than 2-3 days each (so, between 12-15 mosques in total) and, upon completion, they would return to the Dewsbury centre again for the final 24 hours. During this final day, an appointed spokesperson (again, decided internally in the jama'at (group) through mashwera and appointed by the amir) would feed-back (karguzari) the group's experiences to the assembled audience at Dewsbury and, before departing back home, the Dewsbury elders would offer parting advice to the group about establishing TJ activities in their local Scottish mosques and encourage them to return annually for their chillah (40-day outing). Should the outgoing group arriving at Dewsbury comprise of more experienced, dedicated members (usually, those who have already undertaken the signature four-month khuruj to the movement's South Asian headquarters) rather than young neophytes, then it is quite possible that they would be dispatched to an international, rather than national, destination, quite literally anywhere in the world. Again, any incoming TJ group formed in a markaz elsewhere in the world and dispatched to the UK would first make a beeline for the Dewsbury headquarters straight from the airport, where the elders, after the due processes of mashwera, would decide where in the UK to send them for the duration of their tour. We thus see how TJ's national headquarters in Dewsbury is a central transit point both for incoming and outgoing TJ groups, and it is quite usual, when visiting the centre, to meet groups that have just arrived from or are about to depart to far-flung corners of the world (see Figures 4 and 5).

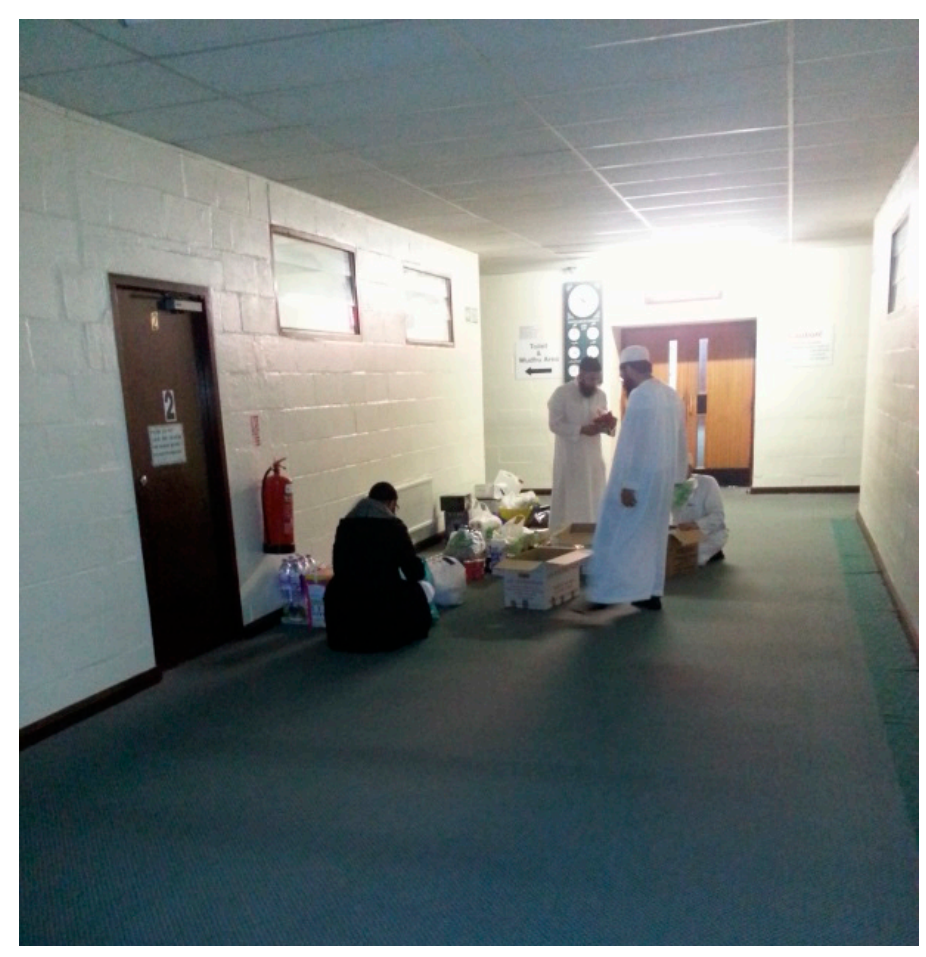

Figure 4. A young British-born TJ group packing their provisions in Dewsbury before departing on an international 40-day TJ excursion in November 2013. Source: author's photo. 


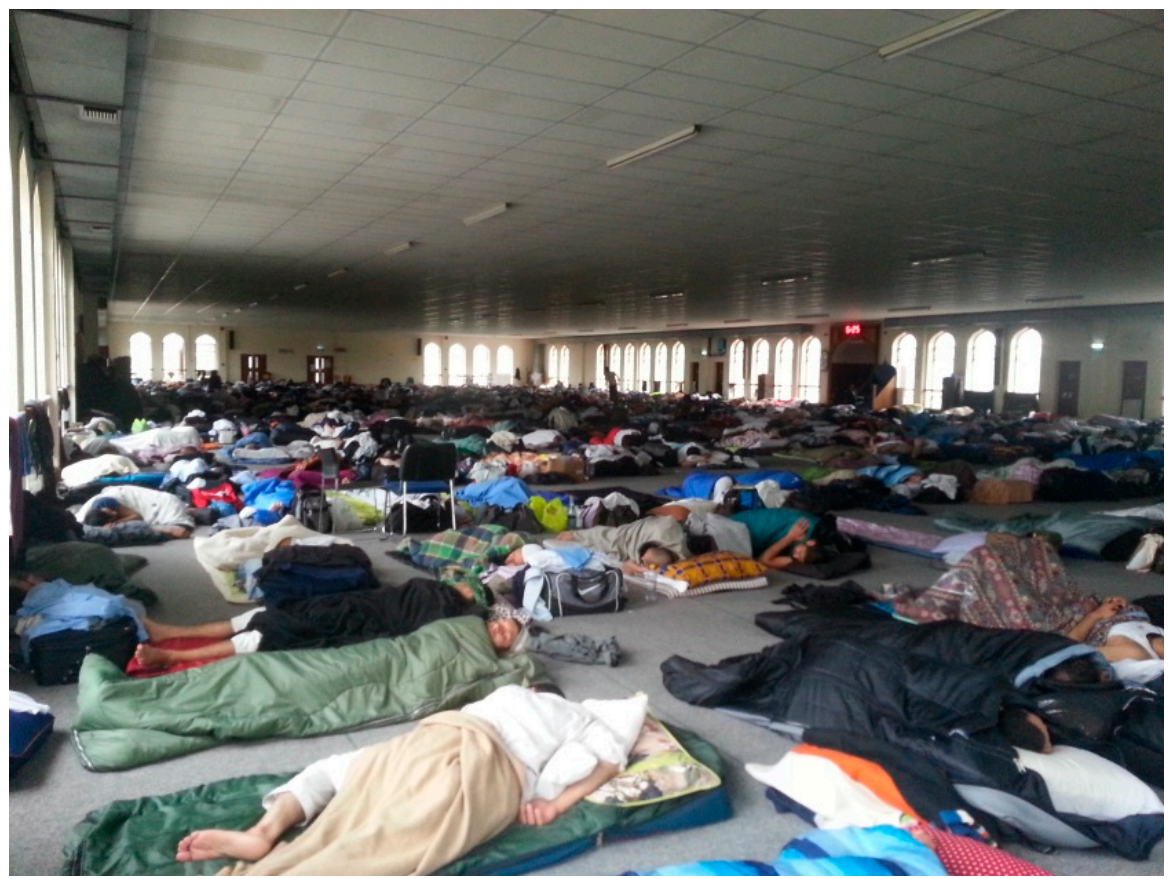

Figure 5. The upper floor of the large TJ complex in Dewsbury strewn, in Ziauddin Sardar's (2004, p. 2) words, with a plethora of "contended logs" taking their sunna siesta nap during the peak summer holiday period in 2014. Source: author's photo.

\section{TJ and the Local Mosques}

\subsection{Accessing Mosques of Different Denominational Affiliations}

While the Dewsbury Markaz functions as a central hub, its national activity depends upon a network of regional maraakiz (plural of markaz: headquarters/centre) and mosques scattered across the country. Sikand (1998a), in his study of the British branch of TJ, made no mention of the five regional headquarters that have operated for some decades now in Birmingham, Blackburn, Glasgow, Leicester and London; these are briefly highlighted by Pieri in his much later study (Pieri 2012b, p. 30). My fieldwork also uncovered the existence of what I have termed "semi-maraakiz" operating in Bristol, Cardiff, Newcastle and Dublin (more on these below). A key distinction should be made here: the maraakiz are exclusively the preserve of $\mathrm{TJ}$ in that they are administered by $\mathrm{TJ}$ authorities and permit only TJ activities and speeches on their premises; the mosques, by contrast, are managed by local committees and permit a range of activities including, though not limited to, TJ. However, not every mosque in the UK allows TJ activities. According to the website meticulously maintained by Mehmood Naqshbandi, there are over 1800 active mosques and Islamic prayer premises in the UK, of which some 797 (41.2\%) are affiliated with the orientation of Deobandi Islam. ${ }^{10}$ It is safe to assume that $\mathrm{TJ}$ can operate without any resistance in the great majority of these mosques; in fact, it will actively be supported in many by a variety of imams, committee members and regular worshippers (see also King 2002). It is worth noting in this connection that, during the course of my fieldwork, I observed several recently-built British Deobandi mosques that had been architecturally designed to accommodate visiting TJ groups. Specific design features included dedicated sleeping areas, sometimes with their own central heating controls, state-of-the-art kitchens to facilitate jama'at cooking and an easily accessible shower cubicle. Additionally, many British mosques display signs which indicate the movement's entrenchment in the wider ideological architecture (see Figure 6).

10 See www.MuslimsInBritain.org (accessed 21 June 2019). The statistics are derived from a downloadable PDF report compiled on 16 September 2017: http://www.muslimsinbritain.org/resources/masjid_report.pdf. 

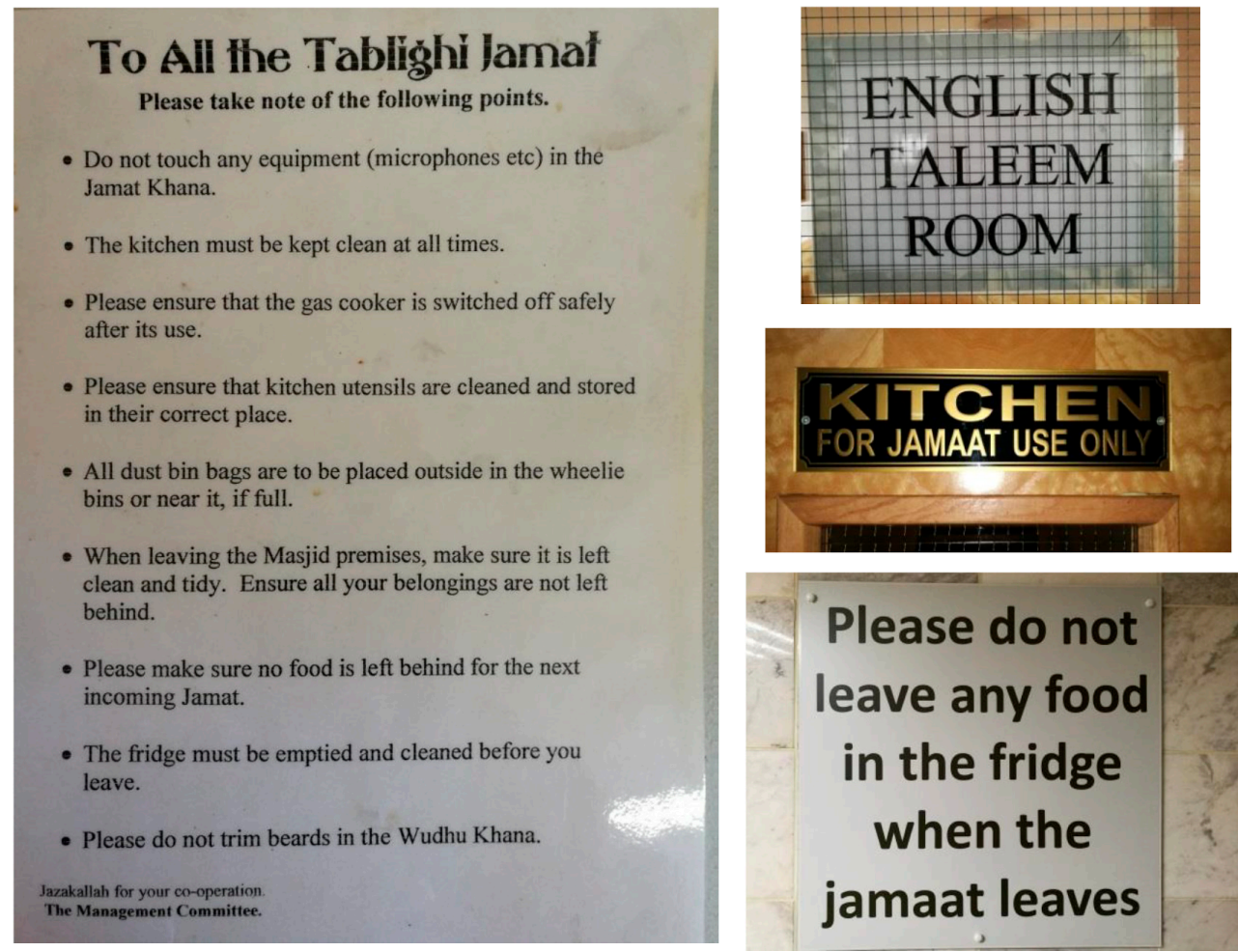

\section{Please do not leave any food in the fridge when the jamaat leaves}

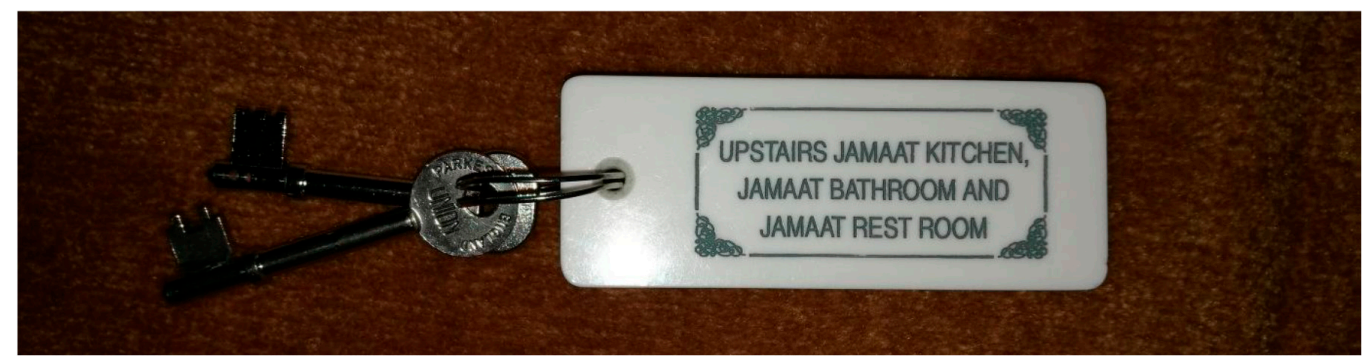

Figure 6. A collection of signs indicating TJ's entrenchment on the landscape of many British mosques. Source: author's photos.

By contrast, due to sectarian differences, TJ will effectively be barred from operating in the majority of Barelwi (459 mosques; $23.7 \%$ ) and Salafi-inspired (182; 9.4\%) mosques-although this is not always the case. For instance, while conducting fieldwork in Birmingham during the summer of 2014, I spent a night with a visiting TJ group from Medina, Saudi Arabia ${ }^{11}$ that was staying in an Arab Salafi mosque. Local activists informed me that that regional TJ authorities, based at the Birmingham Markaz, make a point of sending only Arab TJ groups to mosques of this kind as the usual groups of South Asian ethnic origin are more readily objected to. The cosmopolitan Al-Rahma mosque in Liverpool may be cited as another example. Founded (and still managed) primarily by Muslims of Yemeni and Somali extraction, it can in no way be considered Deobandi, yet it has a long history of allowing TJ groups to visit and stay, permitting them to deliver their talks after the daily prayers. According to Mogra (2014, p. 189), TJ has, in some UK cities, also achieved limited success in accessing mosques of Barelwi and Ahl-e-Hadith orientation as well as those founded by non-South Asian Muslims who "tend to be sympathetic towards TJ, especially for bringing change among some wayward youths". Similarly,

11 Although TJ is officially banned in the Kingdom, I was informed by the group it has a discreet yet robust presence-as is the case in several Middle Eastern countries (see the fascinating article published by the Christian Science Monitor: The mysterious Islamic movement quietly sweeping the Middle East (Luck 2015)). 
Siddiqi (2018, p. 125) finds in Cardiff that the Dar ul-Isra mosque, "affiliated with the ideology of Abul Ala Maududi, the founder of the Jamaat-I Islami", ${ }^{12}$ permits TJ groups to stay and conduct their activities on-site while the Shahjalal and Jalalia mosques, both catering to Muslims of the Bangladeshi Fultoli tradition, allow TJ groups to visit and preach, though not stay overnight. While this calls into question Pieri's (2012b, p. 9) assertion that "All TJ mosques are Deobandi but not all Deobandi mosques are TJ", I think it would nevertheless be safe to assume that $\mathrm{TJ}$ is completely barred from operating in at least a third of the UK's mosques (see Figure 7).

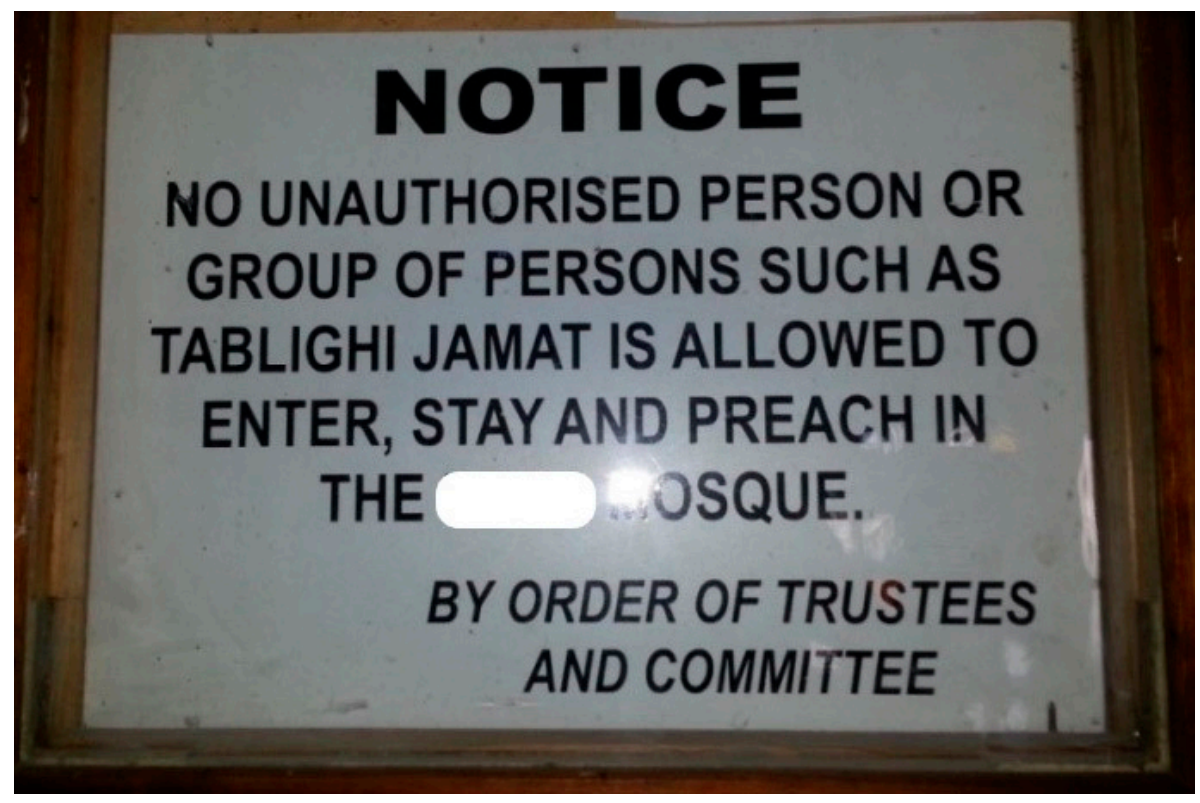

Figure 7. Sign on the noticeboard in a British Barelwi mosque (in terms of the Pakistani context, Ahmad (1991, p. 523) states: “Tablighi Jamaat assemblies are completely banned in the mosques controlled by the Brelvi ulama and their followers"). Source: author's photo.

\subsection{TJ Maraakiz and the Authority of the Sunna}

Where do TJ's large markaz complexes fit on the landscape of British mosques more generally? In a recent paper, Ahmed (2019) deploys the emic terminology of the Islamic tradition to propose a three-tier typology of British mosques. The fard mosque offers no more than the daily (or occasional) prayers, the fard kifaya mosque simultaneously discharges communal obligations pertaining to such matters as rites of passage, while the sunna mosque offers a plethora of additional activities ostensibly rooted in the paradigm of the Prophet's mosque at Medina. The smallest unit of TJ is the itinerant group, united temporarily under an amir, which operates in all three tiers of Ahmed's typology-indeed, in any mosque it will be hosted. However, it is TJ's maraakiz, or headquarters, which would fall within the category of the sunna mosque-not just due to their size, but also because of the volume of personnel and range of activities involved. However, unlike the examples of the East London Mosque or Cardiff's Dar ul-Isra mosque cited by Ahmed, the TJ maraakiz evince virtually no desire to proactively engage with wider non-Muslim society by, for example, holding MP surgeries on-site or hosting interfaith events. Their focus, rather (as elucidated in more detail below), is on managing the activities of large numbers of TJ groups and providing a spiritually charged atmosphere to catalyse the moral

12 However, according to Ahmed (2019, p. 150): “The members of the mosque leadership are equally from Pakistani and Middle-Eastern backgrounds, though its congregation is more diverse..." Having personally visited the mosque on several occasions, I think a more accurate descriptor would simply be "cosmopolitan"-which brings into sharp relief the problems inherent in ascribing labels to people, mosques or organisations that inevitably evolve over time, and the "dynamics of power inherent in the act of naming" (Guenther 2009, p. 412). 
transformation of the individual Muslim. In doing so, and as a movement explicitly geared toward the salvific revival of the sunna (prophetic example), TJ grounds itself in a series of symbolic reference points for which it finds precedence in the lives of the Prophet and his Companions. The grandiose ambition of the "London mega-mosque" project (DeHanas and Pieri 2011), for example, was criticised by a large number of long-standing (and, perhaps tellingly, non-London-based) TJ activists I interviewed for contravening core TJ principles of humility, simplicity and good-neighbourliness—seen to be hallmarks of the sunna. This indicates, as Ahmed suggests, the intrinsic heterogeneity of the sunna category and the way in which it is differently interpreted and mobilised by multiple social actors to infuse with authenticity and authority structures and activities sustained across space and time in the name of Islam.

\section{Ministering the Nation: Regional and Local Divisions of TJ}

Each regional markaz is connected to a network of mosques within which TJ is able to operate to constitute a halqa - translated as area, region or zone-for which it carries ministering responsibility. The UK, for TJ purposes, is therefore divided into six halqas-including, of course, the Yorkshire halqa, whose markaz in Dewsbury also doubles up as the national and European headquarters of the movement. To aid understanding, it may be instructive at this point to sketch a parallel with what is termed the "episcopal polity"13 of traditional Christianity. It is usual for church authorities to map the country along local and regional lines to facilitate administrative and ministering functions. Broadly speaking, the parish comprises the smallest unit of ecclesiastical organisation and roughly equates to the catchment area surrounding a local mosque. Just as numerous parishes taken together constitute a diocese, presided over by a bishop who is properly based in a cathedral, so do numerous mosques taken together constitute a halqa, networked, in TJ terms, to the regional markaz. Similarly, just as the jurisdiction of a particular diocese roughly follows civil boundaries, so does each halga roughly comprise an amalgamation of a number of British counties. Each markaz, given its size and relationship to the individual mosques in its 'diocese', can be equated analogously to a cathedral—although it is administered not by a single bishop but a council of elders appointed (not elected) by the Dewsbury headquarters. From my interviews with several TJ leaders, it seems that a new regional headquarters can only be established following approval from the movement's spiritual centre in Nizamuddin, New Delhi-with Dewsbury, of course, acting as a conduit. In this, it may be useful to elaborate the parallel further with reference to Roman Catholicism which, in terms of numbers of adherents, is incidentally far closer to the British Muslim population than the dominant Church of England. While the latter operates currently in 41 dioceses ${ }^{14}$ —subsumed further into two 'ecclesiastical provinces', York (12 dioceses) and Canterbury (29 dioceses), each with their own Archbishop-the former operates in five ecclesiastical provinces containing a total of 22 dioceses. ${ }^{15}$ Of all Roman Catholic cathedrals in England and Wales, it is the one at Westminster that occupies a special place as the "mother church"; this resembles the special position occupied by Dewsbury Markaz for British TJ (and if we insist on pursuing the parallel even further, it could be suggested that the leadership role exemplified by the recently deceased Archbishop Emeritus Cormac Murphy-O'Connor equates somewhat analogously to that of the late Hafiz Patel). Similarly, just as British Roman Catholicism derives its ultimate authority and directives from the Vatican, so do the top-level hierarchy of British TJ refer back periodically for guidance and advice to the Nizamuddin headquarters in India where the "theoretical, spiritual, and symbolic head of the movement"16 (Reetz 2008, p. 109) resides (see Figure 8).

13 Such an arrangement does not exist in the "congregational polity" of many post-Reformation denominations.

14 With the Diocese in Europe, the total is 42; see https://www.churchofengland.org/about-us/dioceses.aspx (accessed 21 June 2019).

15 See http://catholicfaith.org.uk/Home/Ask-Find/Find-a-church (accessed 21 June 2019).

16 The reference is to Maulana Muhammad Sa'ad Kandhalwi, great-grandson of TJ's founder, although of course this all refers to the situation before the schism outlined in Section 1.2. In recent years, Maulana Sa'ad's authority has been increasingly 


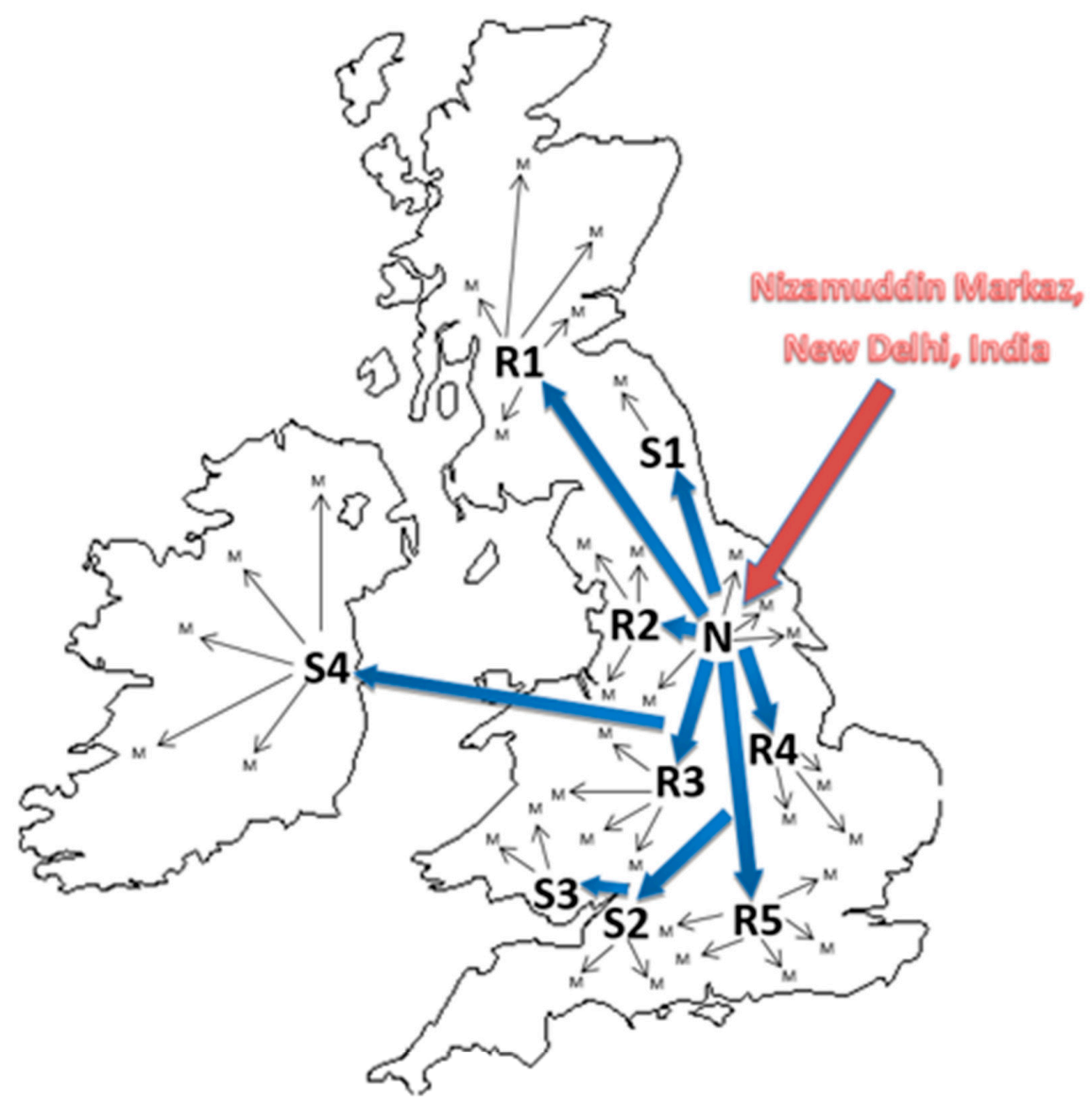

KEY

$\mathrm{N}=$ NATIONAL TJ HEADQUARTERS: DEWSBURY MARKAZ

R1 = REGIONAL TJ HEADQUARTERS: GLASGOW MARKAZ

R2 = REGIONAL TJ HEADQUARTERS: BLACKBURN MARKAZ

S1 = NEWCASTLE SEMI-MARKAZ

R3 = REGIONAL TJ HEADQUARTERS: BIRMINGHAM MARKAZ

S2 = BRISTOL SEMI-MARKAZ

R4 = REGIONAL TJ HEADQUARTERS: LEICESTER MARKAZ

S3 = CARDIFF SEMI-MARKAZ

R5 = REGIONAL TJ HEADQUARTERS: LONDON MARKAZ

$S 4=$ DUBLIN SEMI-MARKAZ

$M=$ LOCAL MOSQUE (DEPICTED SYMBOLICALLY, NOT NUMERICALLY OR GEOGRAPHICALLY)

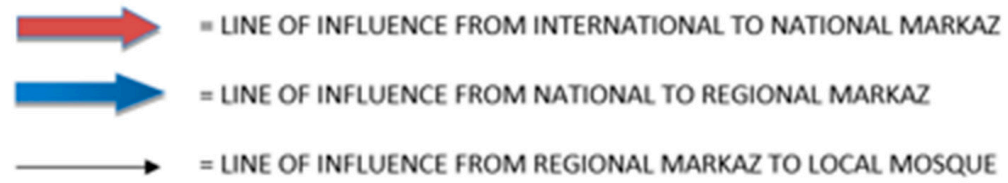

Figure 8. A topography of British TJ.

It is important to specify here the nature of the influence depicted by the arrows in Figure 8. While the national centre exerts considerable influence on the regional ones (but by no means absolute, as demonstrated by Pieri's (2015) study of the relative autonomy exercised by regional London TJ leaders in their bid to secure planning permission for the proposed "mega-mosque"), the regional

contested, and rejected outright by some, in TJ circles, leading to the undermining of the authority of both the Dewsbury and Nizamuddin headquarters for many British Tablighis. However, as stated in Section 1.2, the content of this paper reflects the situation as it was during the period of my fieldwork over 2013-2015, and fresh fieldwork would be required to accurately map subsequent developments. 
centres exercise far less influence on the local mosques. The nature of this influence is restricted to the coterie of TJ activists that gather regularly in each mosque with a TJ presence and relates in no way to the day-to-day administration of the mosque (whether it is Deobandi or non-Deobandi). This administration is managed by the mosque management committee which operates independently of the regional markaz and makes decisions relating to, for instance, the appointment of imams or the curriculum of the evening madrassa with complete autonomy. Only in mosques with a strong TJ presence might the council of elders at the markaz be consulted (often in a private capacity) on such issues, as might the senior ulema of the Dar al-Ulums due to their popular perception as fonts of piety and wisdom. From the perspective of the regional markaz then, it is sufficient for the local mosque to simply permit visiting TJ groups to stay on their premises and carry out their programme of activities while providing adequate kitchen, heating and shower facilities.

As mentioned, many British mosques also have a small presence of dedicated TJ activists who conduct their daily TJ activities on site and who maintain an ongoing link with both their regional markaz as well as the national markaz in Dewsbury. In practice, as TJ is a normative component of the Deobandi institutional infrastructure, TJ leaders, ulema and mosque committee members usually work in concert to facilitate each other's activities within a single mosque setting in which it is broadly recognised that $\mathrm{TJ}$ is but one among a range of permitted religious offerings. This, however, does not always happen without friction. For instance, a local group of dedicated TJ activists may insist on separately conducting their daily $\mathrm{ta}^{\prime} \mathrm{lim}$ (book-reading) session after the Isha prayer at the same time that the imam is conducting his weekly circle on tafsir (Qur'anic commentary). This reinforces the idea that, in some settings, TJ assumes a parochial cliquish identity-as pointed out by the British Deobandi scholar Mufti Muhammad ibn Adam al-Kawthari on the authority of his teacher Mufti Taqi Usmani. ${ }^{17}$ Alternatively, a member of a visiting TJ group might accidentally leave a burn mark on the mosque carpet as he irons his clothes; or a group of youngsters out on a weekend tour might, while playing indoor football at night with a bundle of rolled up socks, damage the expensive chandelier ornamenting the central prayer hall—both of which would, understandably, provoke the ire of the mosque's management committee. Such incidents are not unknown and, in some cases, the regional markaz elders might be called upon to smooth local ruffled feathers and try to facilitate the ongoing visits of jama'ats.

\section{The Functioning of a Regional Markaz}

Two key weekly activities distinguish a markaz from a normal mosque. The first is the "Tuesday evening mashwera" which sees local TJ leaders from across the halqa gather to progress TJ goals. This weekly "synod" attracts a fairly aged crowd of up to 100 long-standing activists, usually with several decades of TJ experience each; every (active TJ) mosque in the halqa is expected to send two or three senior Tablighis to participate in the mashwera. Different regional TJ elders preside over each weekly meeting, and participants offer ideas about how TJ's macro goals can be achieved (see Section 6 for more on these). That a substantial minority of younger, British-born activists are sufficiently experienced to regularly contribute to these meetings now, and sometimes lead them, indicates a level of successful intergenerational transmission within British TJ-a topic I explore in more detail elsewhere (Timol 2017).

The second key activity of a regional markaz is the "Thursday night gathering", which is an open invitation to male Muslims across the halqa to attend an hour-long inspirational lecture, often delivered in Urdu but always with separate English (and, if necessary, Arabic) translation, followed by an appeal (tashkeel) in which assembled audience members are encouraged to volunteer themselves to participate in outgoing TJ tours. Talks are delivered either by committed activists or ulema from across the region, or by members of visiting TJ groups—as determined on a weekly basis by local markaz elders. During

17 See: http://daruliftaa.com/blessed-effort-of-jamaah-al-tabligh (accessed 21 June 2019). 
the course of my fieldwork, I attended several Thursday night gatherings at the Blackburn Markaz (see Figure 9), which invariably attracted a largely youthful crowd of up to 1000 Muslims of mainly South Asian origin from mosques across the halqa including Bolton, Preston, Liverpool, Nelson, Lancaster and, of course, Blackburn. ${ }^{18}$ Following the lecture, many participants proceed downstairs to the bottom storey of the building where a communal meal is served-usually accompanied by much good-natured camaraderie and jovial chatter as TJ activists from across the halqa (who have often spent time together on extended khuruj outings) catch up with each other and newcomers are gently socialised into the movement. The really dedicated (up to 50-100) stay the night each week, only returning home, or going straight from the markaz to their workplaces, after offering the Friday dawn prayer (fajr) in congregation. Given that the night preceding Friday is regarded as being especially blessed, one of the objectives of the overnight stay is to facilitate the rising for the pre-dawn optional tahajjud prayer-a particularly emphasised component of TJ's devotional cosmology.

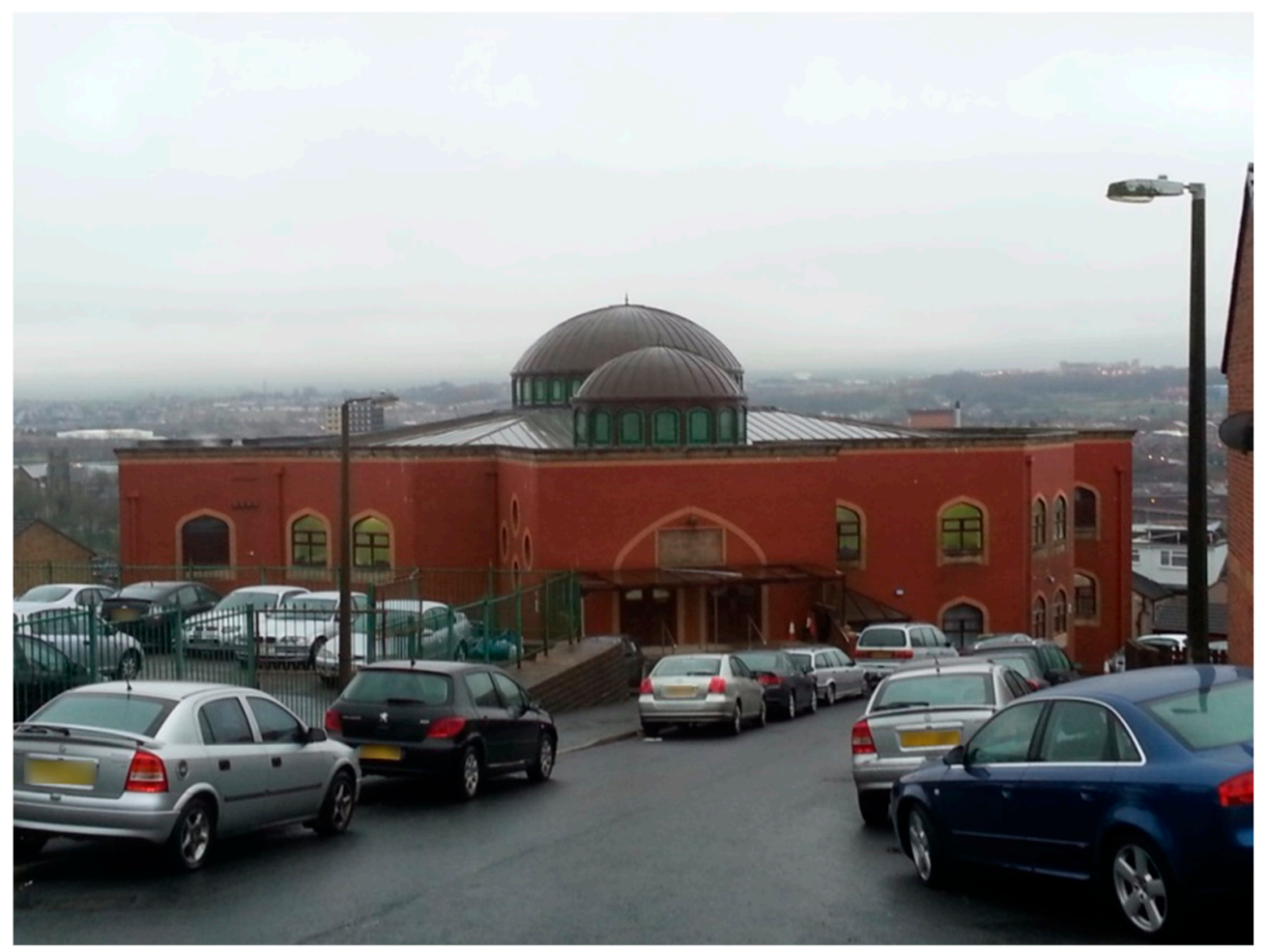

Figure 9. Blackburn Markaz (the number of cars indicating the amount of attendees the weekly programme attracts) Source: author's photo.

Another key activity administered by the regional maraakiz is the weekly management of weekend TJ outings-a staple of the movement's global modus operandi-across the halqa. When attending the Tuesday evening mashwera, it is usual for the TJ leaders of each mosque to inform the markaz elders of the number of jama'ats expected that coming weekend from their local mosque, and whether they are expecting any masturat jama'ats (ladies groups) to be formed. Designated members of the markaz hierarchy then co-ordinate destinations in the halqa for each of the expected groups and write them with a wipe-able marker pen onto a pre-prepared template displayed as one of several oversized noticeboards situated at the administrative hub of the markaz (see Figure 10). Before returning home,

18 The bulk of Pieri's (2012a, p. 39) participant observation consisted of attending the weekly Thursday night gatherings at London Markaz-“ 150 hours (roughly 55 separate sessions) over a period of 18 months were spent attending these talks, followed by further time socialising over a meal in the mosque afterwards"-where he observed that a more ethnically diverse crowd of up to 3000 would gather each week. 
the visiting TJ leaders from the different mosques across the halqa will make their way to the noticeboard to take note of the "routes" given to each of their expected jama'ats. This information will then be relayed to the remainder of the TJ activists in their own mosque, usually at the daily mashwera meeting held after the Fajr prayer the next (Wednesday) morning. Younger activists then often disseminate the destination of that weekend's jama'at to their friends or other potential recruits via WhatsApp or text message (see Figure 11).

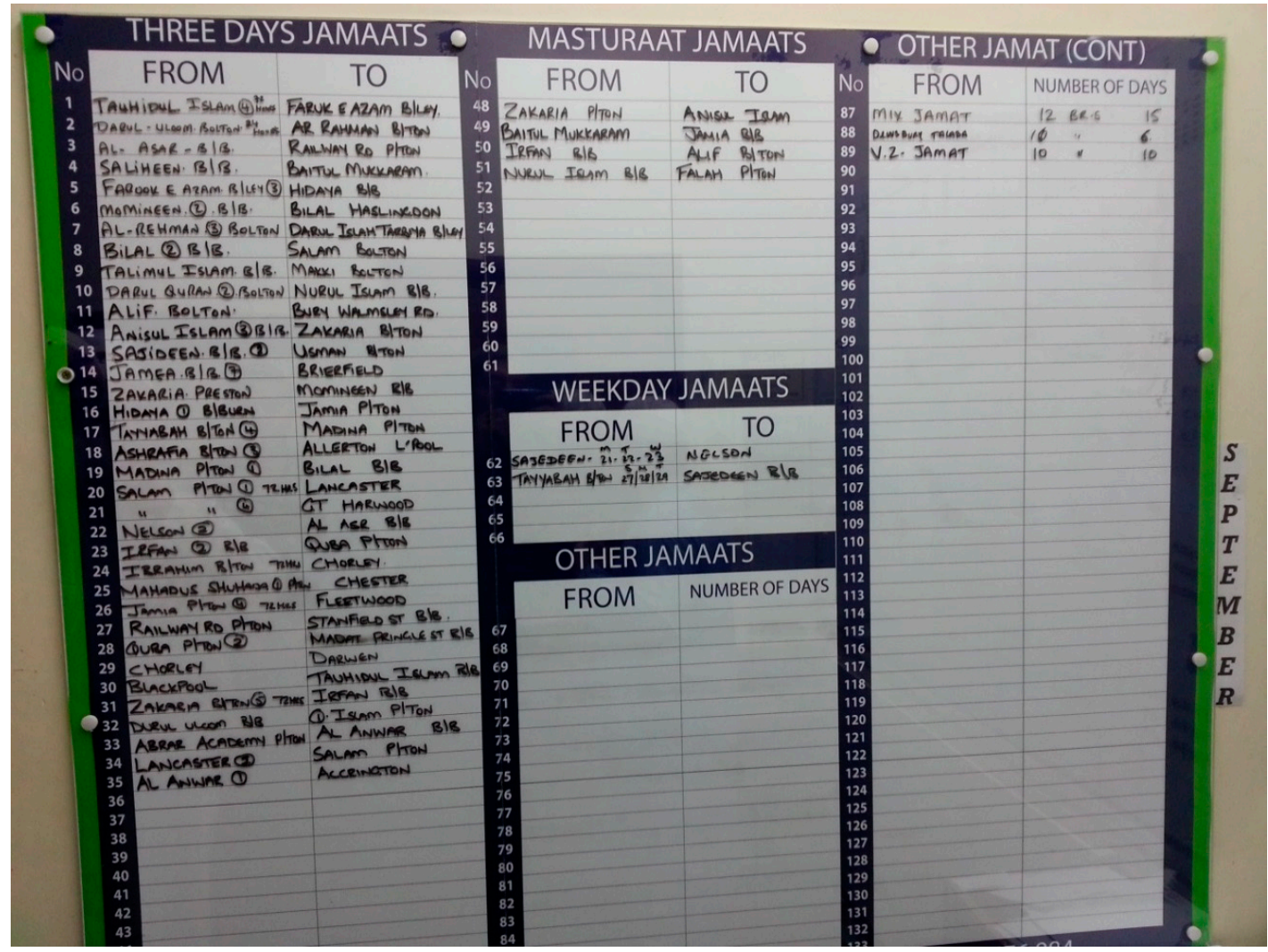

Figure 10. The oversized noticeboard template in Blackburn Markaz, freshly filled out on a Tuesday evening, that displays the "routes" of all the jama'ats operating in the Lancashire halqa on a typical week. Source: author's photo (October 2013).

\section{Salam. Jama'at will be going to Zakariyya Masjid in Bolton this weekend IA. Brothers are requested to be ready with their bedding, etc in Isha salaat on Friday which is at $7.35 \mathrm{pm}$. Jazakallah}

Figure 11. An example of a text message sent out on Wednesday informing potential participants about the coming weekend's jama'at. Source: author's mobile phone.

Figure 10 warrants some commentary. As can be seen: 
- There are 35 men's jama'ats (usually between 8-15 members each) expected that weekend and four ladies' groups (usually comprising 4-6 husband-wife couples each), ${ }^{19}$

- Of the men's jama'ats, five are ready for the full 72 hours (Thursday to Sunday evening), while the majority are for the weekend only (Friday to Sunday evening), and one is only for 24 hours;

- Two weekday jama'ats are also expected (usually consisting of taxi drivers and restaurant workers who find it difficult to join the normal groups due to their occupational commitments over the weekend);

- All the above refer to the weekly 2-3-day TJ outings to be formed, organised and dispatched within the halqa. Additionally, three groups (under the heading 'Other Jamaats') are visiting mosques in Lancashire from outside the halqa. These comprise the following:

1. A "mixed group" (i.e., the individual members hail from different parts of the UK) of 12 people that is probably out for 40 days in total and is spending 15 days in this halqa;

2. A 10-strong group of 'Dewsbury talaba' (i.e., students of the Dewsbury Dar al-Ulum) that is visiting the halqa for 6 days;

3. 'V.Z. Jamat'-i.e., a foreign TJ group from Venezuela visiting the halqa (via Dewsbury, of course) for 10 days and probably in the UK for 40 days in total.

We thus see how 44 separate mosques within the Lancashire halqa were scheduled to host visiting jama'ats on that weekend, chosen at random, in October 2013. Elders at the Blackburn Markaz are therefore evidently required to exercise care to ensure that mosques are not double-booked with more than one visiting jama'at at the same time, and that individual mosques are visited by different TJ groups with fairly uniform frequency. Although the other regional maraakiz (in Birmingham, Dewsbury, Glasgow, Leicester and London) may not follow the same noticeboard system, it is highly probable that they will organise their weekly groups along very similar lines so as to maintain a birds-eye view of the various jama'ats operating within their demarcated zones at any given time.

As mentioned earlier, my fieldwork also uncovered the existence of what I have termed four "semi-maraakiz." These operate in Bristol, Cardiff, Newcastle and Dublin and differ from a full markaz in two important respects. Firstly, they are based in an ordinary mosque (albeit with a strong TJ presence) and not premises exclusively managed by TJ. Secondly, local TJ leaders convene in them weekly only for the Tuesday evening mashwera and to co-ordinate the movement of jama'ats across their local regions; they are not considered strong enough yet-in TJ terms-to host the weekly Thursday-night open programme. The medium-long term goal for each, however, would no doubt be to strengthen the local TJ infrastructure enough to manage this also in dedicated premises, thus establishing another fully-fledged regional markaz.

\section{On the Interface of the Local and Global: TJ's "Glocal" Activism}

Another key institutional activity of British TJ comprises the "mahina mashwera" convened at the national Dewsbury headquarters every 6 weeks or so. It is a weekend-long council attended by several hundred leaders of TJ mosques across the country, thus amalgamating nationally the same long-standing activists who attend the weekly Tuesday evening mashwera in their respective regional maraakiz. Although I did not attend a mahina mashwera, I gauged that it proceeds along a set format in which a large number (around 20 or so) of umoors (agenda items) are discussed over the course of the weekend; it invariably concludes with a tearful supplication $\left(d u^{\prime} a a\right)$ that would historically be offered by Hafiz Patel. Several senior Tablighis informed me that the umoors derive from a higher level "European mashwera" held at the international Nizamuddin spiritual centre every two years

19 Masturat, or ladies TJ groups, in practice comprise of couples. While men stay at the mosque, ladies are hosted in the house of a local volunteer. For more on the female TJ experience, see Amrullah (2011) or Janson (2014). 
(similar continental-wide mashweras are also held biennially there for other global territories such as Africa or South East Asia, for example). Here, national TJ leaders from various European countries (and select others) gather for several days to discuss macro TJ goals which are then broken down and agreed at the country level with the Nizamuddin authorities. The mahina mashwera is a key mechanism designed to facilitate the achievement of these national goals calibrated across a two-year period (that is, between European mashweras). There is also an interim level—between the global and national-in which, every three months, TJ leaders from across Europe gather for a weekend-long mashwera in different European countries selected on a rotation basis where they feed-back on national activities and monitor the progress of the macro European goals decided at Nizamuddin. At the national level, on the next (Monday) evening following a given weekend mahina mashwera held at the Dewsbury Markaz, TJ activists from each "diocese" gather at a pre-stipulated "parish" mosque that is selected on a rotation basis, or alternately gather at the regional markaz. Here, the handful of local elders that attended the Dewsbury gathering relay a condensed version of the discussions to the much larger number of regionally gathered activists, and the national umoors are thus broken down a level further. Ultimately, individual TJ activists return to their own mosques to implement the agreed outcomes at a micro-level, as depicted in Figure 12.

It may be helpful to illustrate the staggered nature of this activism with an example. For instance, at the biennial European mashwera, the Nizamuddin headquarters may have requisitioned (takaza) from the Dewsbury centre six 40-day jama'ats from the UK to tour a specified range of European countries every three months. At the mahina mashwera, this would be one of the many umoors discussed, and each of the regional halqas might take upon themselves the responsibility of contributing one jama'at each (thus making up the required total of six). At the regional Monday evening follow-up, individual mosques might take upon themselves the responsibility of contributing one member each for the jama'at agreed at halqa level. Names of potential candidates would then be discussed and a list drawn up at the local mosque's daily mashwera meeting. Next, individuals would be visited and tashkeeled (encouraged to participate) during the daily gasht (preaching) activity of each local "parish" mosque (see (Reetz 2003) for more on TJ's "Local Mosque Scheme"). Progress would be monitored at a halqa level at the weekly Tuesday evening mashweras held at the regional maraakiz and, ideally, the assembled jama'at would make their way to Dewsbury Markaz within the stipulated timeframe ready to begin their 40-day tour. At the next European mashwera at Nizamuddin, the Dewsbury (and other national) authorities would be required to feed-back (karguzari) on how well objectives were achieved over the preceding two years; accordingly, problems might be brainstormed and fresh macro objectives set for the coming two years.

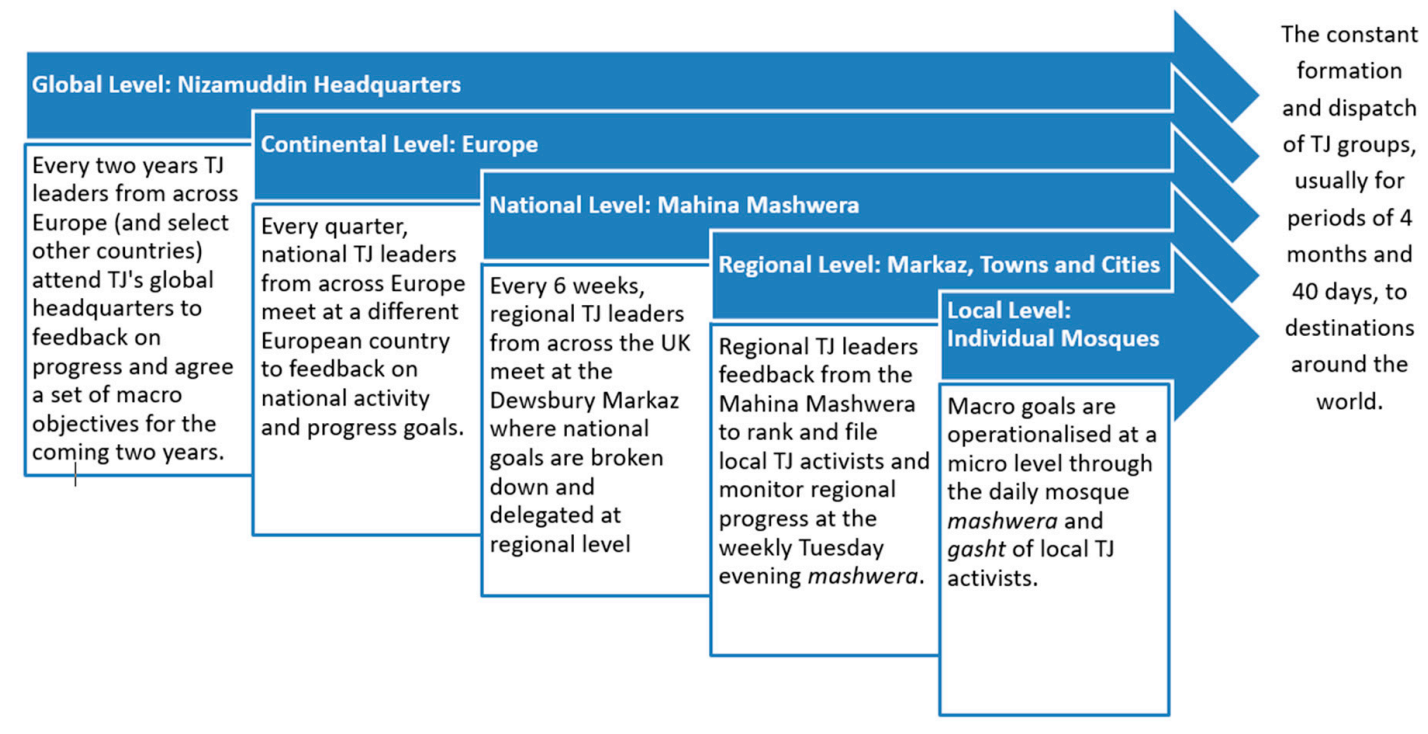

Figure 12. The mechanics of TJ's "glocal" activism. 
This measured and calculated style of activism, which encompasses local, regional, national and international dimensions, is commented upon by Reetz (2008, p. 111) in his analysis of TJ's "faith bureaucracy" in its Indian context: "Thus, a huge map of religious activity and performance is imagined of the country and the whole world. It is not unlike the target map of a huge global corporate enterprise, setting course on expansion" (also see Figure 13). Ali, a 37-year-old English convert to Islam who has spent the last two decades as a dedicated TJ activist, expressed a similar sentiment when describing to me his first international TJ khuruj to the Raiwind headquarters in 1998:

"It was really the next level and masha' Allah, you know, I met so many people from around the world and I did meet committed people so it was a real kind of, the performance bar was increased, you know, you saw people who were giving so many hours a day and they were very devoted to the teachings of Islam and yeah, it was a really good environment to be in ... it felt like a genuine, I mean basically the layout was almost like a business plan which is: this is what we want to achieve, these are the outcomes that we want to achieve, these are the kind of performance indicators, you know, it was like a very clear business plan. How people can benefit from the religion of Islam and how the Muslims can be a source of benefit for mankind and serve mankind and be a source of good for mankind. And again, that resonated with me, and it seemed like a very clear game plan which I've heard lots of other groups of people but I never saw a very practical, clear plan as this."

The practical ramifications of this glocal activism become evident when considering that eight of my formal interviewees who worshipped in a single mosque in the North of England had, between them, visited, over two decades of staunch TJ commitment, the following countries (usually for a minimum 40-day khuruj but sometimes for a longer four-month outing): America, Argentina, Australia, Austria, Bangladesh, Barbados, Belgium, Bosnia, Brazil, Bulgaria, Canada, Denmark, Fiji Islands, Finland, France, Germany, Greece, Holland, India, Indonesia, Italy, Kosovo, Malta, New Zealand, Pakistan, Panama, Romania, Saudi Arabia, South Africa, Spain, Sri Lanka, Sweden, The Philippines, Trinidad \& Tobago and Venezuela. That seven of the eight were British-born further indicates the extent of successful intergenerational transmission of the movement in Britain and exposes the lacuna that exists in extant studies of British Islamic youth activism.
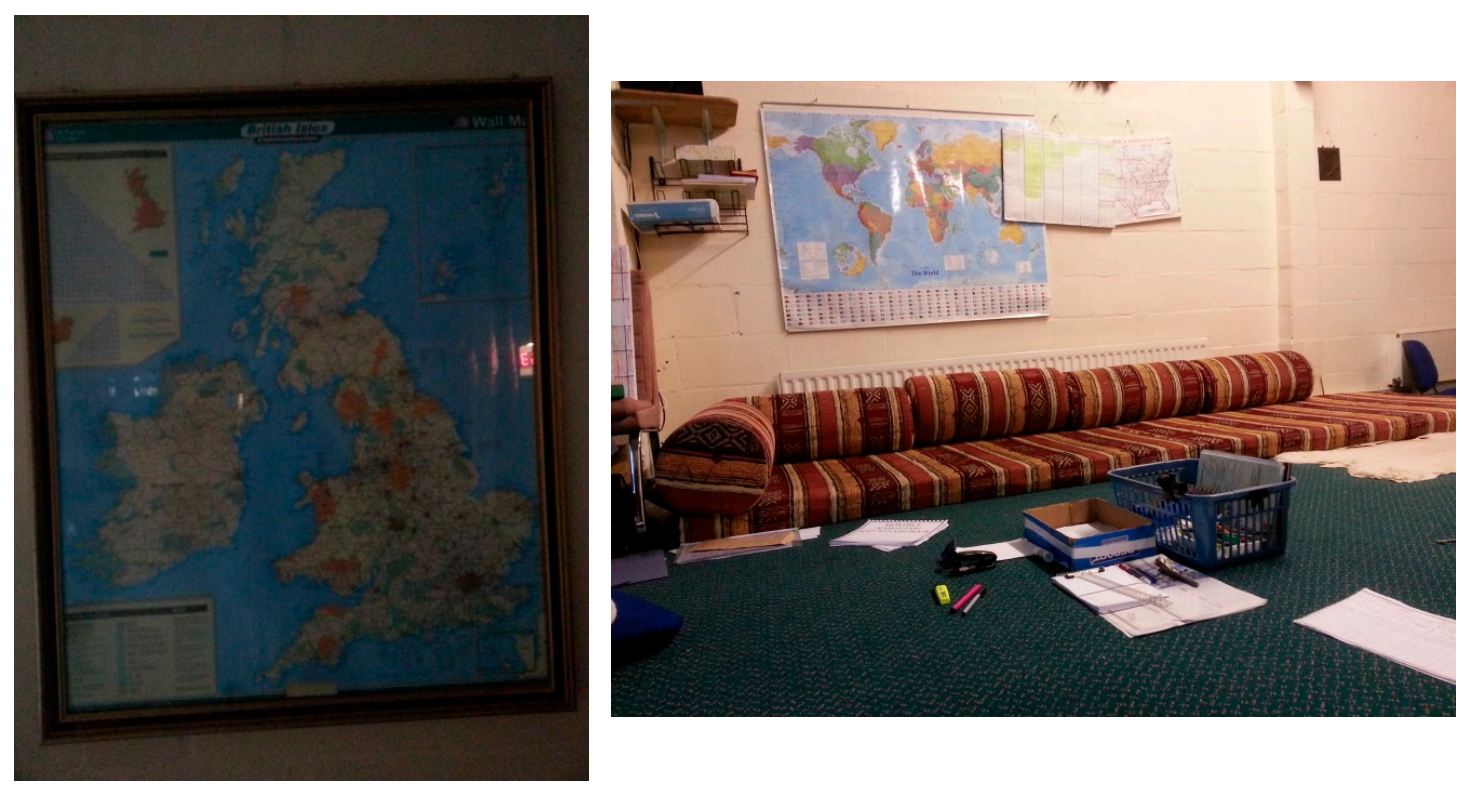

Figure 13. It is noteworthy that national and international maps adorn the walls of the Dewsbury headquarters, although critics maintain that it has failed to engage adequately with the wider society on its doorstep (Lockwood 2012). Source: author's photos. 


\section{Conclusion}

This paper has described the Tablighi Jama'at's institutional organisation and modalities of operation in the British context. In doing so, it has highlighted the systematic manner in which local, regional, national and international levels of the movement interact to produce a truly "glocal" movement. It has also identified the basic geographic sites at which British TJ operates from hundreds of individual mosques scattered around the country to the national headquarters situated in Dewsbury, with various regional maraakiz (in Birmingham, Blackburn, Glasgow, Leicester and London) and semi-maraakiz (in Bristol, Cardiff, Newcastle and Dublin) acting as conduits. While the institutional organisation of the movement in Britain has recently splintered, following the death of its spiritual leader Hafiz Patel in February 2016 and the simultaneous development of a seemingly insoluble schism at the level of the global hierarchy, this paper has captured the ordinary structures of authority that have characterised its operation in Britain throughout the bulk of its history. In this, it has built upon Reetz's $(2003,2008)$ work in the South Asian context and helped fill evident lacunae subsisting in the British context (Sikand 2002; Siddiqi 2018). In particular, the paper fleshes out Pieri's (2015) valuable overview of British TJ's organisational structures with an unprecedented level of detail based on freshly undertaken ethnographic fieldwork. Triangulating the findings with studies conducted elsewhere—such as Janson's (2014, pp. 91-95) description of Gambian TJ's organisational structure-indicates the extent to which TJ has managed to spread its activities across vast geographical expanses whilst maintaining a supranational uniformity of method. However, this global—or glocal—proliferation, as was pointed out earlier, often escapes public attention. According to Mandaville (2001, p. 146), “It is in groups such as the Tablighi Jama'at ... that the umma, in the sense of a community of believers unhindered by geographical or national boundaries, finds its truest expression in Islam today". While there is no doubt that this ethos of radical egalitarianism constitutes a striking element of TJ's normative praxis (as also attested to by Metcalf (1994) among others), this paper has argued that it simultaneously camouflages a structured hierarchy of authority and an elaborate system of organisation crucial to its basic functioning. Not only does the Tablighi Jama'at operate on the interface of the local and the global then, but it also exemplifies a type of regulated fluidity and a distinct "absent presence" (Kinnvall and Svensson 2017) that defies simplistic categorisation.

Funding: I wish to record my gratitude to the Jameel Scholarship Programme which made possible the research upon which this article is based.

Conflicts of Interest: The author declares no conflict of interest. The funders had no role in the design of the study; in the collection, analyses, or interpretation of data; in the writing of the manuscript, or in the decision to publish the results.

\section{References}

Ahmad, Mumtaz. 1991. Islamic Fundamentalism in South Asia: The Jama'at-Islami and the Tablighi Jama'at of South Asia. In Fundamentalisms Observed. Edited by Martin E. Marty and Scott R. Appleby. Chicago: University of Chicago Press.

Ahmed, Abdul-Azim. 2019. Conceptualising Mosque Diversity. Journal of Muslims in Europe 8: 138-58. [CrossRef]

Ali, Jan Ashik. 2012. Islamic Revivalism Encounters the Modern World: A Study of the Tablighi Jama'at. New Delhi: Sterling Publishers.

Amrullah, Eva F. 2011. Seeking sanctuary in 'the age of disorder': Women in contemporary Tablighi Jamā'at. Contemporary Islam 5: 135-60. [CrossRef]

Balci, Bayram. 2015. The rise of the Jama'at al Tabligh in Kyrgyzstan: The revival of Islamic ties between the Indian subcontinent and Central Asia? Central Asian Survey 31: 61-76. [CrossRef]

Birt, Jonathan, and Sophie Gilliat-Ray. 2010. A mosque too far? Islam and the limits of British multiculturalism. In Mosques in Europe: Why A Solution Has Become A Problem. Edited by Allievi Stefano. London: Alliance Publishing Trust-Network of European Foundations. 
Birt, Jonathan, and Philip Lewis. 2012. The Pattern of Islamic Reform in Britain: The Deobandis Between Intra-Muslim Sectarianism and Engagement with Wider Society. In Producing Islamic Knowledge: Transmission and Dissemination in Western Europe. Edited by van Bruinessen and Stefano Martin. London: Routledge.

Bowen, Innes. 2014. Medina in Birmingham, Najaf in Brent: Inside British Islam. London: C Hurst \& Co Publishers Ltd.

Coffey, Amanda. 1999. The Ethnographic Self: Fieldwork and the Representation of Identity. London: SAGE Publications Ltd.

DeHanas, D. N., and Z. P. Pieri. 2011. Olympic Proportions: The Expanding Scalar Politics of the London 'Olympics Mega-Mosque' Controversy. Sociology 45: 798-814. [CrossRef]

Dhorat, Muhammad Saleem. 2018. Hafiz Muhammad Patel Sahib. Riyadul Jannah 27.

Geaves, Ron. 1996. Sectarian Influences Within Islam in Britain with Reference to the Concepts of 'ummah' and 'community'. Edited by Kim Knott. Leeds: University of Leeds.

Ghazali, Abdus Sattar. 2018. Global leadership split in Tablighi Jamaat echoes in San Francisco Bay Area. Available online: https://countercurrents.org/2018/10/global-leadership-split-in-tablighi-jamaat-echoes-insan-francisco-bay-area (accessed on 21 June 2019).

Gilliat-Ray, Sophie. 2006. Educating the Ulama: Centres of Islamic religious training in Britain. Islam and Christian-Muslim Relations 17: 55-76. [CrossRef]

Guenther, Katja M. 2009. The politics of names: Rethinking the methodological and ethical significance of naming people, organizations, and places. Qualitative Research 9: 411-21. [CrossRef]

Hamid, Sadek. 2011. British Muslim Young People: Facts, Features and Religious Trends. Religion, State and Society 39: 247-61. [CrossRef]

Hamid, Sadek. 2015. Sufis, Salafis and Islamists: The Contested Ground of British Islamic Activism. London: I.B.Tauris \& Co Ltd.

Hammersley, Martyn, and Paul Atkinson. 2007. Ethnography: Principles in Practice, 3rd ed. London: Routledge.

Iqbal, Sajid. 2018. A House Divided. Dawn. Available online: https://www.dawn.com/news/1391624 (accessed on 21 June 2019).

Janson, Marloes. 2014. Islam, Youth and Modernity in the Gambia: The Tablighi Jama'at, The International African Library. Cambridge: Cambridge University Press.

Khan, Arsalan. 2016. Islam and Pious Sociality: The Ethics of Hierarchy in the Tablighi Jamaat in Pakistan. Social Analysis: The International Journal of Anthropology 60: 96-113. [CrossRef]

King, John. 2002. Tablighi Jamaat and the Deobandi mosques in Britain. In Global Religious Movements in Regional Context. Edited by John Wolffe. Bath: Ashgate Publishing Ltd in Association with The Open University.

Kinnvall, Catarina, and Ted Svensson. 2017. Ontological security and the limits to a common world: Subaltern pasts and the inner-worldliness of the Tablighi Jama'at. Postcolonial Studies 20: 333-52. [CrossRef]

Lewis, Philip. 1994. Islamic Britain: Religion, Politics and Identity among British Muslims. London: I.B.Taurus.

Lockwood, Danny. 2012. The Islamic Republic of Dewsbury. Batley: The Press News Ltd.

Luck, Taylor. 2015. The Mysterious Islamic Movement Quietly Sweeping the Middle East. Available online: http://www.csmonitor.com/World/2015/1206/The-mysterious-Islamic-movement-quietly-sweepingthe-Middle-East (accessed on 21 June 2019).

Madden, Raymond. 2010. Being Ethnographic. London: SAGE Publications Ltd.

Mandaville, Peter. 2001. Transnational Muslim Politics: Reimagining the Umma. London: Routledge.

Mandaville, Peter. 2010. Muslim Networks and Movements in Western Europe. Washington, DC: The Pew Forum on Religion \& Public Life.

Masud, Muhammad Khalid, ed. 2000. Travellers In Faith: Studies of the Tablighi Jama'at as a Transnational Islamic Movement for Faith Renewal. Leiden: Koninklijke Brill NV.

Metcalf, Barbara. 1994. Remaking Ourselves: Islamic Self-Fashioning in a Global Movement of Spiritual Renewal. In Accounting for Fundamentalisms: The Dynamic Character of Movements. Edited by Martin E. Marty and Scott R. Appleby. Chicago \& London: University of Chicago Press.

Mogra, Imran. 2014. The Tablighi Jama'at in the UK. In Islamic Movements of Europe: Public Religion and Islamophobia in the Modern World. Edited by Frank Peter and Rafael Ortega. London: I.B. Tauris \& Co. Ltd.

Noor, Farish. A. 2012. Islam on the Move: The Tablighi Jama'at in Southeast Asia. Amsterdam: Amsterdam University Press. 
Pieri, Zacharias. 2012a. The Contentious Politics of Socio-Political Engagement: The Transformation of the Tablighi Jamaat in London. Ph.D. thesis, University of Exeter, Exeter, UK.

Pieri, Zacharias. 2012b. Tablighi Jamaat-Handy Books on Religion in World Affairs. London: Lapido Media.

Pieri, Zacharias. 2015. Tablighi Jamaat and the Quest for the London Mega Mosque: Continuity and Change. New York: Palgrave Macmillan.

Reetz, Dietrich. 2003. Keeping Busy on the Path of Allah: The Self-Organisation (Intizam) of the Tablighi Jama'at. In Islam in Contemporary South Asia. Edited by D. Bredi. Rome: Oriente Moderno.

Reetz, Dietrich. 2008. The Faith Bureacracy of the Tablighi Jama'at: An Insight into their System of Self-organization. In Colonialism, Modernity, and Religious Identities: Religious Reform Movements in South Asia. Edited by Gwilym Beckerlegge. Oxford: Oxford University Press.

Reetz, Dietrich. 2009. Tablighi Jama'at. In The Oxford Encyclopaedia of the Islamic World. Edited by John Esposito. Oxford: Oxford University Press.

Sardar, Ziauddin. 2004. Desperately Seeking Paradise: Journeys of a Sceptical Muslim. London: Granta Books.

Schleifer, Abdallah, ed. 2018. The 10th Anniversary Edition, The World's 500 Most Influential Muslims, 2019. Amman: The Royal Islamic Strategic Studies Centre.

Shaw, Martin. 2016. 'At least 5000' mourners turn up to funeral of respected Muslim leader in Yorkshire town. The Mirror. Available online: http://www.mirror.co.uk/news/uk-news/at-least-5000-mourners-turn-7404184 (accessed on 21 June 2019).

Siddiqi, Bulbul. 2018. Becoming 'Good Muslim': the Tablighi Jamaat in the UK and Bangladesh. Singapore: Springer.

Sikand, Yoginder S. 1998a. The origins and Development of Tablighi-Jama'at (1920-2000): A Cross-Country Comparative Study. Ph.D. thesis, University of London, London, UK.

Sikand, Yoginder S. 1998b. The origins and growth of the Tablighi Jamaat in Britain. Islam and Christian-Muslim Relations 9: 171-92. [CrossRef]

Sikand, Yoginder S. 2002. The Origins and Development of Tablighi-Jama'at (1920-2000): A Cross-Country Comparative Study. Hyderabad: Orient Longman.

Taylor, Jenny. 2015. Understanding and Engaging with the Tablighi Jamaat. Lausanne Global Analysis 4. Available online: https://www.lausanne.org/content/lga/2015-11/understanding-and-engaging-with-thetablighi-jamaat (accessed on 21 June 2019).

Timol, Riyaz. 2015. Religious Travel and the Tablighī Jamā’at: Modalities of Expansion in Britain and Beyond. In Muslims in the UK and Europe I. Edited by Yasir Suleiman. Cambridge: Centre of Islamic Studies, University of Cambridge.

Timol, Riyaz. 2016. Obituary: Hafiz Patel (1926-2016)_'A Spiritual Giant in an Age of Dwarfs'. Available online: http://www.onreligion.co.uk/blogs/obituary-hafiz-patel-a-spiritual-giant-in-an-age-of-dwarfs/ (accessed on 28 February 2016).

Timol, Riyaz. 2017. Spiritual Wayfarers in a Secular Age: The Tablighi Jama'at in Modern Britain. Ph.D. thesis, Cardiff University, Cardiff, UK.

(C) 2019 by the author. Licensee MDPI, Basel, Switzerland. This article is an open access article distributed under the terms and conditions of the Creative Commons Attribution (CC BY) license (http://creativecommons.org/licenses/by/4.0/). 